\title{
Leaves and Seeds as Materials for Flow Cytometric Estimation of the Genome Size of 11 Rosaceae Woody Species Containing DNA-Staining Inhibitors
}

\author{
Iwona Jedrzejczyk and Elwira Sliwinska \\ Laboratory of Molecular Biology and Cytometry, Department of Plant Genetics and Biotechnology, \\ University of Technology and Life Sciences, Kaliskiego Avenue 7, 85-789 Bydgoszcz, Poland \\ Correspondence should be addressed to Elwira Sliwinska, elwira@utp.edu.pl
}

Received 31 December 2009; Revised 20 February 2010; Accepted 1 April 2010

Academic Editor: João Loureiro

Copyright (C 2010 I. Jedrzejczyk and E. Sliwinska. This is an open access article distributed under the Creative Commons Attribution License, which permits unrestricted use, distribution, and reproduction in any medium, provided the original work is properly cited.

\begin{abstract}
The presence of some secondary metabolites in the cell cytosol can cause a stoichiometric error in the flow cytometric estimation of nuclear DNA content. There is no fully reliable method to completely eliminate the effect of these compounds on nuclei fluorescence, and therefore using plant organs/parts free of staining inhibitors is recommended. Eleven species of Rosaceae with high concentrations of propidium-iodide-staining inhibitors were studied to check the possibility of using seeds instead of leaves for genome size estimation. Despite optimizing the concentration and composition of antioxidants in nuclei-isolation buffer for each species, the effect of cytosolic compounds present in the leaves could not be avoided entirely. None of the seeds of the studied species contained inhibitors, and they produced histograms of good quality. The genome size of the studied species ranged from 1.15 to $3.17 \mathrm{pg} / 2 \mathrm{C}$; for 10 species the DNA content was estimated for the first time.
\end{abstract}

\section{Introduction}

The Rosaceae family is economically very important because many of the species are cultivated for their fruits (e.g., Malus, Pyrus, Prunus, Fragaria, and Rubus) or have ornamental value (Rosa). It has been well studied, although the systematic position and evolution of many taxa are still not clear. Knowledge of the genome size would be helpful in their classification. Within the Rosaceae, polyploidy series from diploid to 12-ploid or higher occur $[1,2]$. Since the chromosomes are small and often numerous, ploidy estimation by chromosome counts is difficult. In addition, microscopic chromosome counting is time-consuming and limited to a few tissues. Therefore, flow cytometry (FCM) is a more convenient alternative for establishing the ploidy/genome size of Rosaceae species.

Flow cytometry, a fast and accurate method for the estimation of DNA content, has become the predominant technique for establishing plant genome size $[3,4]$. The most common procedure of sample preparation involves chopping plant organs/tissues (mainly leaves) in a nucleiisolation buffer and measuring the fluorescence of a fluorochrome intercalated into the DNA double helix [5]. The composition of the isolation buffer is critical for accurate FCM measurements. Besides facilitating the isolation of intact nuclei, it should maintain their stability, prevent their aggregation, protect DNA from degradation, and provide an appropriate environment for specific and stoichiometric staining of nuclear DNA [6]. During the last decade, one of the most challenging problems faced by FCM users has been adjusting the buffer composition to the requirements of specific species, especially if they contain staining inhibitors such as phenols, caffeine, and other secondary metabolites in the cytosol of their leaf cells [6-10]. Many species of the Rosaceae family, especially woody plants, belong to this "difficult" group $[1,11,12]$. Special and more timeconsuming procedures have been applied to analyze their DNA content by flow cytometry, involving two-step nuclei extraction and a staining protocol, and/or optimizing buffer composition by the addition of antioxidants $[1,2,13-15]$. 
As shown before $[6,10,11,16]$ and in the present paper, the buffer composition as well as the antioxidant choice and concentration should be optimized individually, which involves additional, often multiple and time-consuming steps before genome size estimation. Omitting such steps can result in inaccurate estimation of the nuclear DNA content. Thus, a simple procedure for sample preparation of these difficult species would speed up analysis of their genome size as well as of the genome composition of allopolyploid/hybrid species.

Despite many studies, there is little information on the mode of action of the staining inhibitors and no universal method to completely avoid their effects on DNA content estimation ([4, 17] and references therein). Inhibition probably involves the intercalation of secondary metabolites into DNA and/or their direct reaction with the dye molecule that interferes with its fluorescence $[7,10]$. The addition of antioxidants, such as polyvinylpyrrolidone, $\beta$-mercaptoethanol, or dithiothreitol to a buffer, although helpful, does not always guarantee the correct measurement of DNA content, especially if added in too low concentration ([11, 18], this study). Since the composition and concentration of secondary metabolites is different in different species/tissues, even buffers currently developed for "difficult" species; for example, woody plant buffer (WPB: [6]) cannot be considered as suitable for all of them. Moreover, for the leaves or even leaf buds of some species that contain a lot of secondary metabolites or/and mucilage, flow cytometry has yielded largely uninformative results (e.g., Polystachia, Ulmus, Betula, Thymus, Rhododendron, Drosera, Viburnum [17, 19, 23], Jedrzejczyk and Sliwinska, unpublished results). Therefore, using a plant organ/part that is free of inhibitors is a better alternative for genome size estimation. For example, for Betula, young, winterdormant twigs have been utilized [19]. Our previous reports showed that leaves can be replaced by seeds for genome size estimation $[18,20,21]$. The mature embryos of orthodox seeds (e.g., seeds that acquire desiccation tolerance during development and may be stored in the dry state) usually contain most of their cells arrested in the $G_{0} / G_{1}$ phase of the cell cycle (for review see [22]) and thus are suitable for establishing the $2 \mathrm{C}$-value. The presence of nuclei of different ploidies (endosperm or endoreduplicated embryo nuclei) in some seeds can be overcome by the isolation and utilization of a part where this has not occurred (usually the radicle).

It is generally assumed that DNA content estimates by flow cytometry become more reliable as histogram quality improves, with $\mathrm{CV}$ and debris measures typically regarded as the best measures of quality $[3,6,23]$. Previous reports [18] have shown that DNA content measures may differ between seeds and leaves but we present for the first time an analysis of the relative sample quality of seed and leaf tissue. The Roseaceae was selected for this study to test the idea that seeds may be a good alternative to leaves in difficult plant species.

The aim of the present study was to find if the seeds of the 11 Rosaceae woody species containing staining inhibitors in the leaf cytosol are free of such compounds, to compare the quality of the FCM histograms of the leaf and seed nuclei, and determine the genome size of those two materials to check their suitability. We tried to neutralize the effect of the staining inhibitors present in leaves by addition of antioxidants, in concentration and composition established individually for each species. However, in most cases this did not improve the histogram quality parameters to the level of those of the inhibitor-free tissue of the seeds. The effect of the antioxidants on propidium iodide (PI) fluorescence of the nuclei isolated from inhibitor-free tissue (seeds) was studied also. We suggest that using seeds allows the application of a standard one-step protocol to prepare a nuclear sample, without the necessity for time-consuming optimization of buffer composition and the risk of incomplete suppression of inhibitor activity by antioxidants. To the best of our knowledge, for 10 out of the 11 species this also is the first report on their genome size.

\section{Materials and Methods}

2.1. Plant Material. Nuclear DNA content was estimated in the leaves and seeds of 11 species of trees and shrubs belonging to the Rosaceae family (Table 1). All the species except Prunus padus (Prunoidae; $x=8$ ) belong to the Spiraeoideae $(x=17)$ subfamily. Plant material (depending on availability, collected from one to three specimens of each species) originated from the Botanical Garden of the Kazimierz Wielki University in Bydgoszcz, Poland. Each studied specimen is recorded in the garden database. Fruits were collected in October-November 2007 and 2008; seeds were removed, dried, and stored at $4{ }^{\circ} \mathrm{C}$ until the following summer, to be analyzed at the same time as the leaves. Young, fully developed leaves were collected in August and analyzed within 2-3 days; during this period they were stored in humid filter paper at $4^{\circ} \mathrm{C}$. Petunia hybrida $(\mathrm{P} \times \mathrm{Pc} 6 ; 2.85 \mathrm{pg} / 2 \mathrm{C}$ : [24]) and Zea mays (CE-777; 5.43 pg/2C: [25]) were used as internal standards.

The whole seed (including seed coat) of Amelanchier stolonifera, Crataegus coccinea, Malus floribunda, P. padus, and Sorbus intermedia, half seed with the radicle (including seed coat) for all species of Cotoneaster genus, and the radicle of Pyrus elaeagrifolia were used to prepare flow cytometric samples. For internal standards, a single radicle tip ( $Z$. mays) or 30-40 whole seeds (P. hybrida) were co-chopped with the target species seed or seed part. For species of the Cotoneaster genus, 2 or 3 leaves were included in a sample, and for the other species, and the internal standards, leaf blade fragments of about $0.5-1 \mathrm{~cm}^{2}$ were included. Single samples contained either nuclei from leaves or from seeds of the target species and the internal standard.

2.2. Flow Cytometry. The test for the presence of PI-staining inhibitors in the leaves and seeds of all species was performed following the protocol of Price et al. [7]. For nuclei isolation, Galbraith's buffer [5], supplemented with PI $(50 \mu \mathrm{g} / \mathrm{mL})$ and ribonuclease A $(50 \mu \mathrm{g} / \mathrm{mL})$, was used. PI fluorescence of two samples was compared: sample 1 that contained nuclei isolated from the leaf/leaves or the radicle tip/seeds of an internal standard (Z. mays or P. hybrida, depending on the species: Table 2 ), and sample 2 that contained nuclei 
TABLE 1: Presence of staining inhibitors in leaves and seeds of trees and shrubs belonging to the Rosaceae family. SH: shrub; TR: tree.

\begin{tabular}{|c|c|c|c|c|}
\hline \multicolumn{2}{|c|}{ Species name } & \multirow{2}{*}{ Life habit } & \multicolumn{2}{|c|}{ Presence of inhibitors } \\
\hline Latin & Common & & Leaves & Seeds \\
\hline $\begin{array}{l}\text { Amelanchier stolonifera } \\
\text { Wieg. }\end{array}$ & Running Serviceberry & $\mathrm{SH}$ & + & - \\
\hline $\begin{array}{l}\text { Cotoneaster dammeri } \\
\text { "Royal Carpet" }\end{array}$ & Bearberry Cotoneaster & $\mathrm{SH}$ & + & - \\
\hline $\begin{array}{l}\text { Cotoneaster divaricatus } \\
\text { Rehd. et Wils. }\end{array}$ & Spreading Cotoneaster & $\mathrm{SH}$ & + & - \\
\hline $\begin{array}{l}\text { Cotoneaster hjelmqvistii } \\
\text { Flinck \& Hylmö }\end{array}$ & Hjelmqvist's Cotoneaster & $\mathrm{SH}$ & + & - \\
\hline $\begin{array}{l}\text { Cotoneaster horizontalis } \\
\text { Decne. "Variegatus" }\end{array}$ & $\begin{array}{l}\text { Rockspray (Herring } \\
\text { Bones) Cotoneaster }\end{array}$ & $\mathrm{SH}$ & + & - \\
\hline $\begin{array}{l}\text { Cotoneaster veitchii } \mathrm{G} . \\
\text { Klotz }\end{array}$ & $\begin{array}{l}\text { Many-flowered } \\
\text { Cotoneaster }\end{array}$ & $\mathrm{SH}$ & + & - \\
\hline Crataegus coccinea $\mathrm{L}$. & Scarlet Hawthorn & $\mathrm{TR}$ & + & - \\
\hline $\begin{array}{l}\text { Malus floribunda Sieb. ex } \\
\text { Van Houtte }\end{array}$ & Japanese Crabapple & $\mathrm{TR}$ & + & - \\
\hline Prunus padus L. & Bird Cherry & TR & + & - \\
\hline Pyrus elaeagrifolia Pall. & Oleaster-leafed Pear & TR & + & - \\
\hline $\begin{array}{l}\text { Sorbus intermedia } \\
\text { (Ehrh.) Pers. }\end{array}$ & Swedish Whitebeam & $\mathrm{TR}$ & + & - \\
\hline
\end{tabular}

TABLE 2: 2C DNA content of leaves and seeds of trees and shrubs belonging to the Rosaceae family.

\begin{tabular}{|c|c|c|c|c|}
\hline \multirow{2}{*}{ Species name } & \multirow{2}{*}{ Internal standard* } & \multirow{2}{*}{ Buffer** } & \multicolumn{2}{|c|}{ 2C DNA $(\mathrm{pg}$, mean $\pm \mathrm{SD})$} \\
\hline & & & Leaves & Seeds \\
\hline Amelanchier stolonifera & 2 & $\mathrm{~B}$ & $2.59 \pm 0.02 \mathrm{a}^{* * *}$ & $2.55 \pm 0.01 \mathrm{~b}$ \\
\hline Cotoneaster dammeri & 2 & $\mathrm{C}$ & $1.41 \pm 0.01^{\mathrm{ns}}$ & $1.41 \pm 0.02$ \\
\hline Cotoneaster divaricatus & 2 & $\mathrm{C}$ & $2.78 \pm 0.01 \mathrm{a}$ & $2.73 \pm 0.02 b$ \\
\hline Cotoneaster hjelmqvistii & 2 & $\mathrm{C}$ & $2.74 \pm 0.03 \mathrm{a}$ & $2.70 \pm 0.01 \mathrm{~b}$ \\
\hline Cotoneaster horizontalis & 2 & $\mathrm{C}$ & $2.77 \pm 0.03^{\mathrm{ns}}$ & $2.77 \pm 0.02$ \\
\hline Cotoneaster veitchii & 2 & $\mathrm{C}$ & $2.67 \pm 0.02 \mathrm{a}$ & $2.63 \pm 0.02 \mathrm{~b}$ \\
\hline Crataegus coccinea & 2 & $\mathrm{~B}$ & $3.16 \pm 0.02^{\mathrm{ns}}$ & $3.17 \pm 0.02$ \\
\hline Malus floribunda & 1 & $\mathrm{~B}$ & $1.45 \pm 0.01^{\mathrm{ns}}$ & $1.44 \pm 0.01$ \\
\hline Prunus padus & 1 & $\mathrm{~B}$ & $1.15 \pm 0.02^{\mathrm{ns}}$ & $1.15 \pm 0.02$ \\
\hline Pyrus elaeagrifolia & 1 & A & $1.15 \pm 0.01^{\mathrm{ns}}$ & $1.15 \pm 0.02$ \\
\hline Sorbus intermedia & 2 & B & $2.82 \pm 0.01^{\mathrm{ns}}$ & $2.81 \pm 0.02$ \\
\hline
\end{tabular}

*1: Petunia hybrid; 2: Zea mays'; **A: Galbraith's + 1\% (w/v) PVP-10; B: Galbraith's + 1.5\% (w/v) PVP-10; C: Galbraith's + 2\% (w/v) PVP-10 + 15 mM $\beta$ mercapthoethanol; ***2C-values in leaves and seeds of the certain species (in lines) followed by different letters are significantly different at $P=.05$ (Student's $t$-test); ns: no significant difference.

released simultaneously from the leaf or seed(s)/seed part of a target species and an internal standard. To prepare a sample, selected plant parts were chopped with a sharp razor blade in a plastic Petri dish with $1 \mathrm{~mL}$ of the buffer. The suspension was passed through a $50 \mu \mathrm{m}$ mesh nylon filter. Samples prepared from leaves were analyzed after about 10 minutes of incubation on ice, and samples prepared from seeds after 20-30 minutes [18]. For each sample, fluorescence in at least 7000 nuclei (across all peaks) was measured using a CyFlow SL Green (Partec GmbH, Münster, Germany) flow cytometer, equipped with a high-grade solid-state laser with green light emission at $532 \mathrm{~nm}$, long-pass filter RG $590 \mathrm{E}, \mathrm{DM} 560 \mathrm{~A}$, as well as with side (SSC) and forward (FSC) scatters. Analyses were performed on five replicates.
Histograms were analyzed using the FloMax (Partec GmbH, Münster, Germany) software.

For establishing the concentration and combination of antioxidants that stabilize PI fluorescence in leaf samples, a test for inhibitors was repeated using Galbraith's buffer with the addition of $1 \%(\mathrm{w} / \mathrm{v})$ polyvinylpyrrolidone (PVP-10; buffer A). For samples from species which after application of buffer A still showed decreased fluorescence of the nuclei of the internal standard, the concentration of PVP in the buffer was increased to $1.5 \%(\mathrm{w} / \mathrm{v})$ (buffer B) and the inhibitor test performed again. For Cotoneaster species, which still showed the inhibition effect on PI fluorescence when buffer $\mathrm{B}$ was applied, the combination of $2 \%(\mathrm{w} / \mathrm{v}) \mathrm{PVP}$ and $15 \mathrm{mM}$ $\beta$-mercaptoethanol (buffer C) was applied. A sample was 
TABLE 3: Effect of antioxidants on flow cytometric estimation of $2 \mathrm{C}$ DNA content in seeds of selected species belonging to the Rosaceae family.

\begin{tabular}{llc}
\hline Species name & \multicolumn{2}{c}{ 2C DNA (pg, mean \pm SD) } \\
$\begin{array}{c}\text { Buffer without } \\
\text { antioxidants }\end{array}$ & $\begin{array}{c}\text { Buffer with } \\
\text { antioxidants* }\end{array}$ \\
\hline Amelanchier stolonifera & $2.56 \pm 0.01^{\mathrm{ns}}$ & $2.55 \pm 0.01$ \\
Cotoneaster divaricatus & $2.74 \pm 0.01^{\mathrm{ns}}$ & $2.73 \pm 0.01$ \\
Crataegus coccinea & $3.18 \pm 0.02^{\mathrm{ns}}$ & $3.17 \pm 0.01$ \\
Malus floribunda & $1.45 \pm 0.01^{\mathrm{ns}}$ & $1.44 \pm 0.00$ \\
Prunus padus & $1.15 \pm 0.01^{\mathrm{ns}}$ & $1.15 \pm 0.01$ \\
\hline
\end{tabular}

*For a certain species the buffer as stated in Table 2 was applied; ns: no significant difference between the values in lines (Student's $t$-test, $P=.05$ ).

prepared and analyzed as described above. Analyses were performed on five replicates.

An additional test was performed to study the effect of the presence of antioxidant(s) in a buffer on the estimation of the 2C-value in seeds of selected species (Table 3 ). The nuclei were isolated using Galbraith's buffer without any antioxidant and buffer supplemented with antioxidant/combination of two antioxidants suitable for the certain species, as established in the previous experiment (Table 2). Measurements were performed on five replicates, using the same procedure of sample preparation and analysis as in the previous two experiments. Nuclear DNA content was calculated using the linear relationship between the ratio of the $2 \mathrm{C}$ peak positions of the target species/internal standard on the histogram of fluorescence intensities.

For measurements of genome size in the leaves and seeds, selected plant parts of the target species and of the internal standard were chopped simultaneously using buffer A, B, or C (Table 2). Analyses were performed on 10 replicates, using the same procedure as in the previous experiments. In addition to nuclear DNA content, a debris background factor (DF) before the application of signals gating was calculated according to the following equation [10]:

DF

$$
\begin{aligned}
= & \frac{\text { Total number of particles }- \text { Total number of intact nuclei }}{\text { Total number of particles }} \\
& \times 100 \% .
\end{aligned}
$$

The results were estimated using a one-way analysis of variance and a Student's $t$-test $(P=.05)$.

\section{Results and Discussion}

Many species, especially woody and medicinal plants, produce numerous secondary metabolites that interfere with the staining of DNA by intercalating fluorochromes and thus cause a stoichiometric error in DNA content measurements $[1,6,11,12,16,26,27]$. The addition of antioxidants to the isolation buffer in many cases seems to have no measurable effect on reducing this interference $([7,18,27]$, this paper). Additionally, the quantity of inhibitor(s) is apparently environmentally regulated $[28,29]$, which makes this method unreliable even if the optimal antioxidant concentration for certain species appears to have been established. Therefore, using tissues that contain such compounds for flow cytometric estimation of DNA content should be avoided. In the present research, a test for the presence of staining inhibitors showed that while the leaves of all the studied species contained compounds that biased the fluorescence of the internal standard nuclei (basing on our experience, the shift of the $G_{0} / G_{1}$ peak of the internal standard by at least three channels on the 512-channel scale was considered as indicative of the presence of staining inhibitors in the cytosol of the cells of the target species), their seeds were free of them (Table 1). Nevertheless, to avoid conducting instrument calibration between analyses of different samples, the same buffers (containing PVP or PVP and $\beta$-mercaptoethanol, marked as $\mathrm{A}, \mathrm{B}$, or C) were used for both leaves and seeds. This was appropriate, because experiments using seeds of five species showed that there were no statistically significant differences between the $2 \mathrm{C}$-values of their nuclei isolated with and without antioxidants in the buffer (Table 3, Figure 1). This conclusion is important, since in some laboratories buffers containing antioxidants are used for nuclei isolation even if the plant material does not contain secondary metabolites.

The histograms of the nuclei isolated from seeds were of better quality than those from leaves (Figures 1 and 2, Table 4). In some seed nuclei samples, especially in those containing PVP at high concentrations and $\beta$ mercaptoethanol in the buffer, an additional population of particles appeared (Figures 1(e) and 1(f), arrows); this was eliminated by gating and did not bias DNA content measurements. The signals probably corresponded to complexes of the PI with the antioxidant(s). For all the species but $P$. padus, the CV of the $G_{0} / G_{1}$ peak of the target species seed nuclei was statistically lower than in leaves (Table 4). Also the background debris level (expressed as DF) in most cases was lower when seeds were used for sample preparation instead of leaves (except $C$. dammeri, C. divaricatus, C. veitchii, and $P$. padus). In the leaves of some species, without the addition of antioxidants it was hard even to distinguish the peaks, and/or the peaks were shifted due to a decrease in fluorescence (Figure 2(a)). Even after supplementing the isolation buffer with antioxidants, the extent of debris in the leaf samples was obvious when compared to those from seeds; in some samples it was over $80 \%$ before gating was applied. The SSC and FSC showed the presence of additional particle populations in almost all samples of leaf nuclei (Figures 2(b) and 2(f), arrows), similar to the "tannic acid effect" [10]. They most probably resulted from aggregates of nuclei or parts of nuclei with unspecific particles and of diverse particles devoid of nuclei (inhibitors, antioxidants) with PI stain. We show that in the studied here species there is an association between the presence of inhibition effects and lower sample quality, even in cases in which DNA content measures do not differ. However, while seed histograms quality was higher than the one of leaf histograms in most species when using our protocols, in some cases it might be 


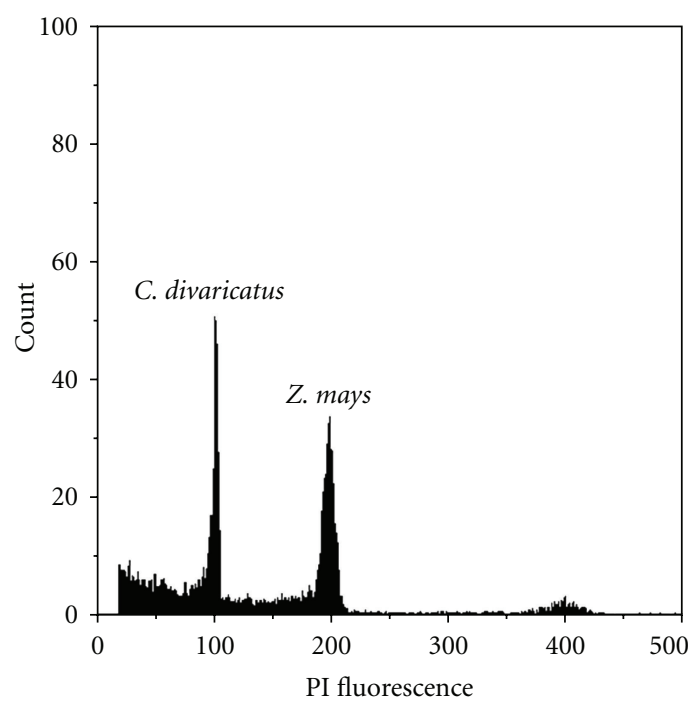

(a)

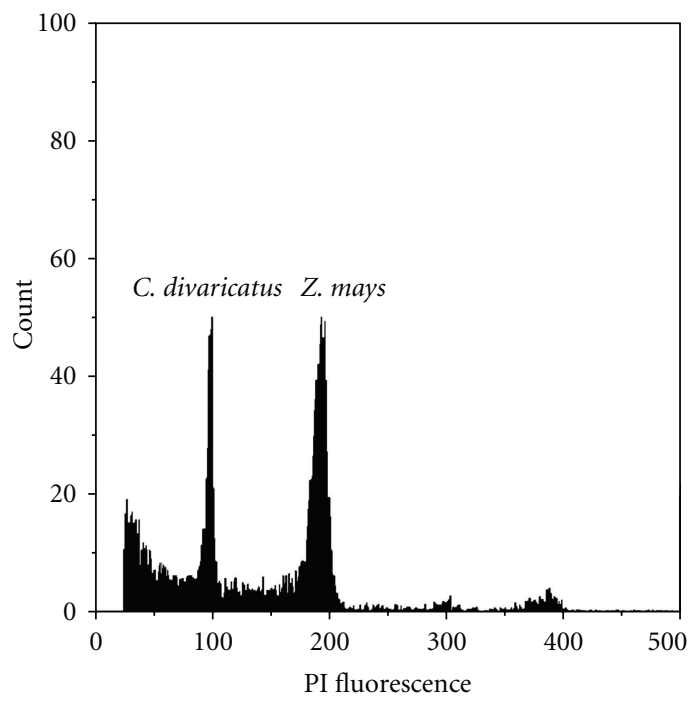

(d)

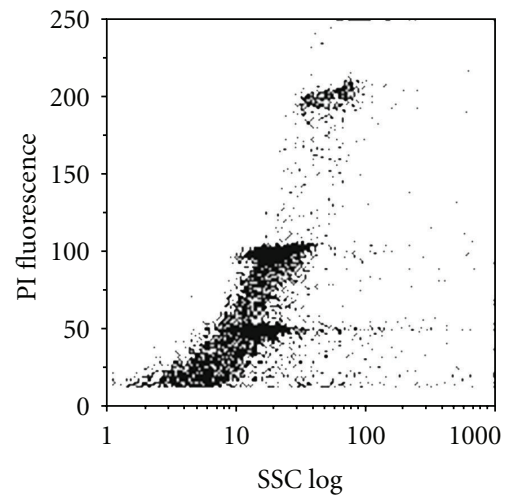

(b)

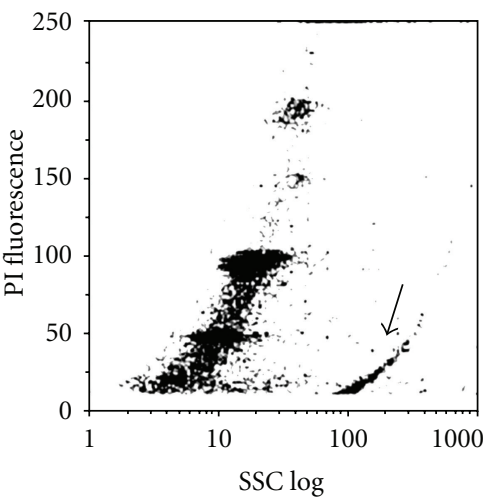

(e)

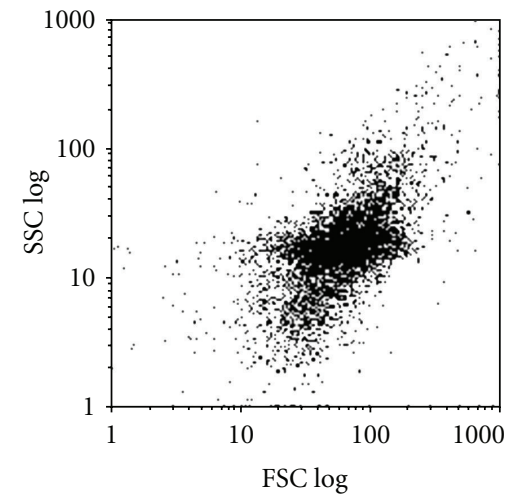

(c)

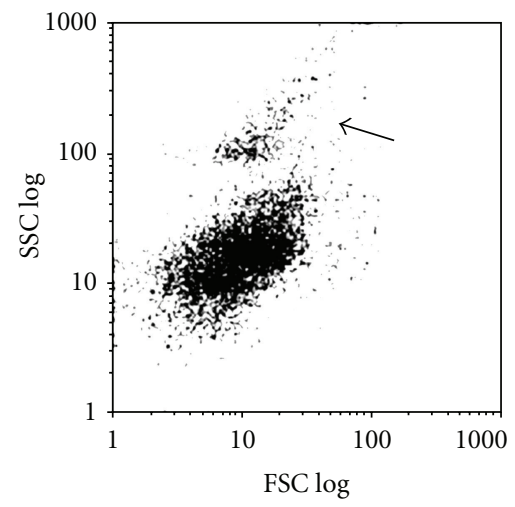

(f)

FIGURE 1: Histograms of PI fluorescence intensity (a, d) and dot plots on side scatter (SSC) versus PI fluorescence (b, e) and forward scatter (FSC) versus SSC (c, f) in the nuclei of seeds of $C$. divaricatus and Z. mays (internal standard) isolated using Galbraith's buffer (a-c) and Galbraith's buffer supplemented with $2 \%(\mathrm{w} / \mathrm{v})$ PVP-10 and $15 \mathrm{mM} \beta$-mercaptoethanol. C. divaricatus does not possess the $4 \mathrm{C}$ nuclei that coincide with the $2 \mathrm{C}$ peak of $Z$. mays. Arrows indicate fluorescent particles without nuclei.

possible to achieve improved results from leaves using other refinements, notably other buffers and/or younger leaf tissue.

The $2 \mathrm{C}$-values obtained for the leaves and seeds were not statistically different for seven out of 11 species (Table 2). However, in the leaves of A. stolonifera and three Cotoneaster species, the $2 \mathrm{C}$-values were higher than in the seeds. A similar tendency was observed previously for $M$. coronaria [30] and Eucalyptus globulus [31]. However, in Helianthus annuus and Brassica napus a higher 2C-value was estimated in the seeds than those in the leaves [18]. Probably the material studied here contained interfering staining inhibitors that they could not be completely eliminated by addition of antioxidants, and thus the overestimated values were due to the reduction of the fluorescence of the internal standard nuclei. Another explanation of the differences between the $2 \mathrm{C}$-values in leaves and seeds could be due to a different chromatin structure in those two organs. Differences in the chromatin condensation were previously observed in different tissues/organs of $Z$. mays [32, 33]. However, in the present experiments it is not likely that the lower estimation of DNA content in some seeds is due to differences in chromatin structure; such differences would be either present in or absent from all species and influence all the measurements, which was not the case. Also, taking into consideration that the DF was similar for both leaves and seeds in two out of four species for which the differences 


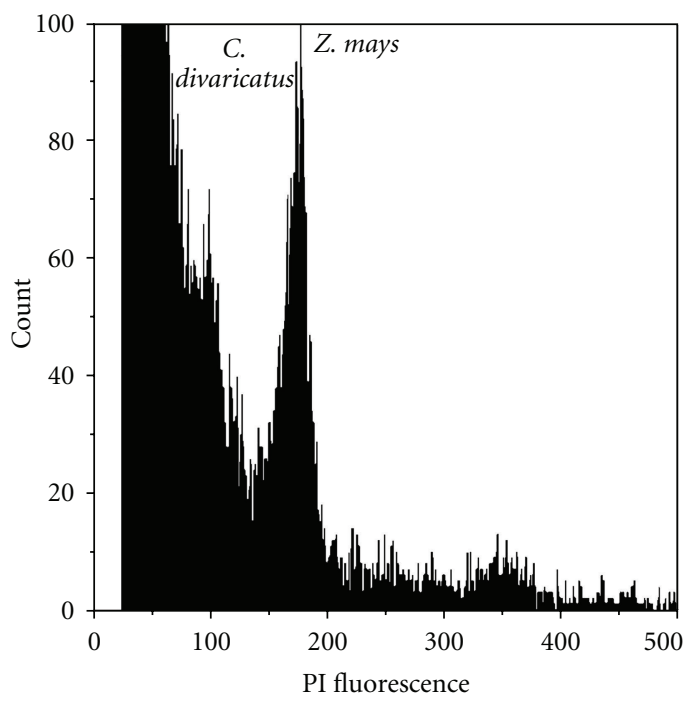

(a)

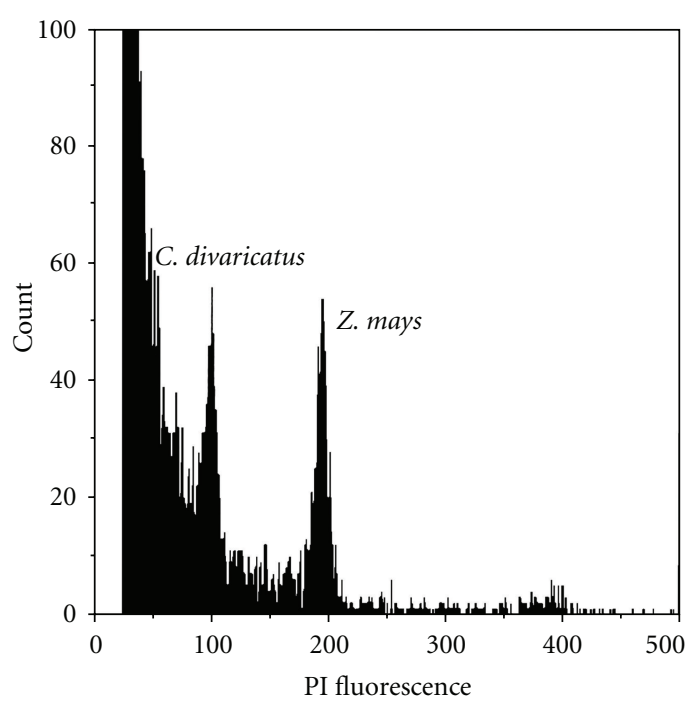

(d)

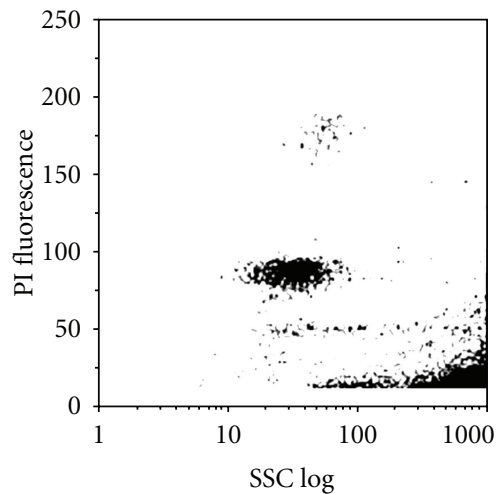

(b)

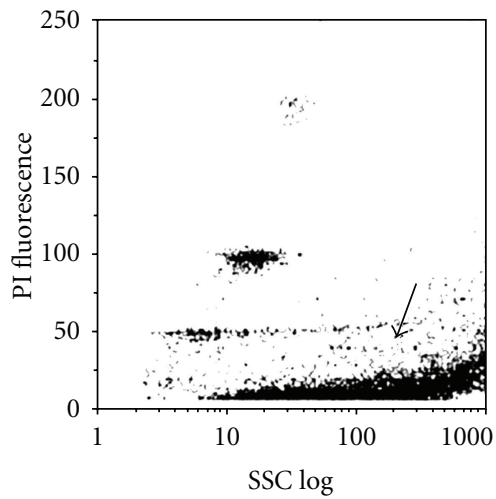

(e)

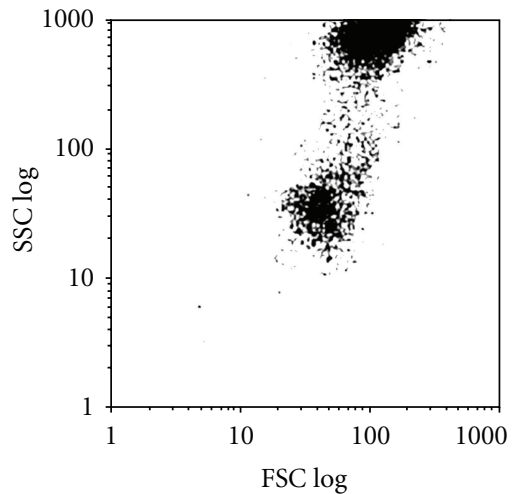

(c)

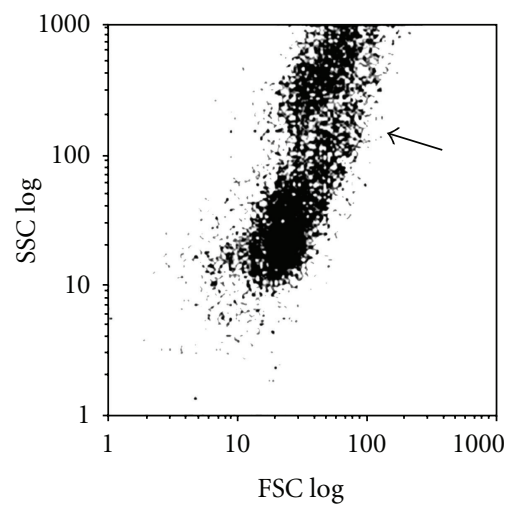

(f)

FIgURE 2: Histograms of PI fluorescence intensity (a,d) and dot plots on side scatter (SSC) versus PI fluorescence (b, e) and forward scatter (FSC) versus SSC (c, f) in nuclei of leaves of C. divaricatus and Z. mays (internal standard) isolated using Galbraith's buffer (a-c) and Galbraith's buffer supplemented with $2 \%(\mathrm{w} / \mathrm{v})$ PVP-10 and $15 \mathrm{mM} \beta$-mercaptoethanol. C. divaricatus does not possess the $4 \mathrm{C}$ nuclei that coincide with the $2 \mathrm{C}$ peak of $Z$. mays. Arrows indicate additional populations of particles (see text for explanation).

in $2 \mathrm{C}$-values occurred, it does not also seem that these were because of difficulties in measuring peak positions due to too much debris.

The $2 \mathrm{C}$-values in the Rosaceae ranges from 0.20 to $7.30 \mathrm{pg}$ [34]. Out of four subfamilies, a relatively large genome size occurs in the Spiraeoideae, which supports the polyploidy origin of this subfamily [1]. The genome size of the species studied here, most of which belong to Spiraeoideae, range from $1.15 \mathrm{pg} / 2 \mathrm{C}$ to $3.17 \mathrm{pg} / 2 \mathrm{C}$. Based on the literature $[1,2,14,15,30,35]$, which provides $2 \mathrm{C}$ values and/or ploidies for Spiraeoideae species related to those studied here, it can be assumed that they are mostly tetraploid, except for Cotoneaster dammeri, M. floribunda, and $P$. elaeagrifolia, which are diploid. Although crosspollination between individuals with different ploidy levels is possible in the Rosaceae, no differences in ploidy were observed here between leaves and seeds originating from the same tree/shrub. Nevertheless, in seeds of species where there is a polyploidy series it is possible that hybridization between plants of different ploidies has occurred, and that the DNA content in the embryo may not correspond to that of the mother plant. In such cases, the leaves of the parent should be analyzed as a ploidy control.

Only for one species studied here, $M$. floribunda was the genome size previously established. Our values, $1.45 \mathrm{pg} / 2 \mathrm{C}$ in the leaf and $1.44 \mathrm{pg} / 2 \mathrm{C}$ in the seed (Table 2), are very close to 
TABLE 4: Quality of the histograms of nuclei isolated from leaves and seeds of trees and shrubs belonging to the Rosaceae family. CV: coefficient of variation for the $G_{0} / G_{1}$ peak; DF: debris background factor.

\begin{tabular}{|c|c|c|c|c|c|c|}
\hline \multirow{2}{*}{ Species name } & \multicolumn{2}{|c|}{ CV of target species $(\%$, mean \pm SD) } & \multicolumn{2}{|c|}{$\mathrm{CV}$ of internal standard $(\%$, mean $\pm \mathrm{SD})$} & \multicolumn{2}{|c|}{$\mathrm{DF}(\%$, mean $\pm \mathrm{SD})$} \\
\hline & Leaves & Seeds & Leaves & Seeds & Leaves & Seeds \\
\hline $\begin{array}{l}\text { Amelanchier } \\
\text { stolonifera }\end{array}$ & $6.54 \pm 0.52 \mathrm{a}^{*}$ & $4.43 \pm 0.43 b$ & $4.09 \pm 0.41 \mathrm{a}$ & $4.63 \pm 0.31 \mathrm{~b}$ & $57.8 \pm 4.3 \mathrm{a}$ & $22.2 \pm 3.6 \mathrm{~b}$ \\
\hline Cotoneaster dammeri & $5.73 \pm 0.68 \mathrm{a}$ & $3.83 \pm 0.39 \mathrm{~b}$ & $2.82 \pm 0.37^{\mathrm{ns}}$ & $3.12 \pm 0.30$ & $78.6 \pm 8.7^{\mathrm{ns}}$ & $67.0 \pm 18.5$ \\
\hline $\begin{array}{l}\text { Cotoneaster } \\
\text { divaricatus }\end{array}$ & $4.52 \pm 0.21 \mathrm{a}$ & $3.35 \pm 0.70 \mathrm{~b}$ & $3.23 \pm 0.51^{\mathrm{ns}}$ & $3.36 \pm 0.45$ & $83.1 \pm 14.4^{\mathrm{ns}}$ & $78.0 \pm 4.9$ \\
\hline $\begin{array}{l}\text { Cotoneaster } \\
\text { hjelmqvistii }\end{array}$ & $4.58 \pm 0.54 \mathrm{a}$ & $4.04 \pm 0.25 \mathrm{~b}$ & $3.53 \pm 0.41 \mathrm{a}$ & $3.98 \pm 0.31 b$ & $56.2 \pm 10.3 \mathrm{a}$ & $38.8 \pm 3.5 b$ \\
\hline $\begin{array}{l}\text { Cotoneaster } \\
\text { horizontalis }\end{array}$ & $5.66 \pm 0.50 a$ & $3.95 \pm 0.40 \mathrm{~b}$ & $4.17 \pm 0.56 \mathrm{a}$ & $3.64 \pm 0.33 b$ & $73.9 \pm 4.3 \mathrm{a}$ & $40.6 \pm 2.8 \mathrm{~b}$ \\
\hline Cotoneaster veitchii & $4.52 \pm 0.57 \mathrm{a}$ & $3.40 \pm 0.76 \mathrm{~b}$ & $3.25 \pm 0.52^{\mathrm{ns}}$ & $3.51 \pm 0.58$ & $75.6 \pm 13.2^{\mathrm{ns}}$ & $66.1 \pm 22.4$ \\
\hline Crataegus coccinea & $5.68 \pm 0.59 a$ & $4.06 \pm 0.35 b$ & $4.46 \pm 0.48 \mathrm{a}$ & $3.42 \pm 0.52 b$ & $47.1 \pm 8.8 \mathrm{a}$ & $31.6 \pm 8.5 \mathrm{~b}$ \\
\hline Malus floribunda & $5.84 \pm 0.74 \mathrm{a}$ & $4.45 \pm 0.25 b$ & $3.78 \pm 0.41^{\mathrm{ns}}$ & $3.79 \pm 0.41$ & $45.2 \pm 6.3 \mathrm{a}$ & $30.1 \pm 3.1 \mathrm{~b}$ \\
\hline Prunus padus & $5.94 \pm 0.42^{\mathrm{ns}}$ & $5.95 \pm 0.45$ & $3.60 \pm 0.39^{\mathrm{ns}}$ & $3.64 \pm 0.40$ & $52.8 \pm 10.2^{\text {ns }}$ & $53.9 \pm 7.8$ \\
\hline Pyrus elaeagrifolia & $5.86 \pm 0.71 \mathrm{a}$ & $4.82 \pm 0.17 \mathrm{~b}$ & $3.81 \pm 0.36 \mathrm{a}$ & $3.36 \pm 0.19 \mathrm{~b}$ & $44.2 \pm 6.9 \mathrm{a}$ & $25.5 \pm 8.8 b$ \\
\hline Sorbus intermedia & $5.78 \pm 0.42 \mathrm{a}$ & $4.36 \pm 0.46 \mathrm{~b}$ & $3.92 \pm 0.30 \mathrm{a}$ & $4.28 \pm 0.36 \mathrm{~b}$ & $53.4 \pm 9.26 \mathrm{a}$ & $34.2 \pm 6.0 \mathrm{~b}$ \\
\hline
\end{tabular}

*Values for leaves and seeds of the certain species and for the certain parameter (in lines) followed by different letters are significantly different at $P=.05$ (Student's $t$-test); ns: no significant difference.

those reported by Tatum et al. (1.46 pg: [15]). Polyploidy in the Crataegus genus has been extensively studied [2, 13, 14]; C. coccinea is reported to be tetraploid, and the DNA content for $4 x$ Crataegus ranges from 2.74 to $3.34 \mathrm{pg} / 2 \mathrm{C}$. Estimations obtained here, $3.16 \mathrm{pg}$ (for leaves) and $3.17 \mathrm{pg}$ (for seeds), fall within this range. There are only single estimations of the genome sizes of species of the genera Amelanchier, Cotoneaster, Pyrus, and Sorbus, but not of those reported here [34]. Thus, our measurements provide 10 new entries to the plant C-value database.

Presently, seeds are not often used for genome size estimation; besides their many advantages they also have some disadvantages. They are convenient because they can be transported and stored dry with no distance or time limit and analyzed at a convenient time. For example, using seeds for genome size estimation has been proposed for desert plants, especially for those that do not develop leaves [20]. However, there can be some confusion in the interpretation of FCM results obtained from seeds due to the presence of cells with a higher than 2C DNA content $[21,22]$. Nevertheless, if the whole seed is not suitable for use, it is usually possible to isolate a tissue or region in which most of the cells are arrested in the $G_{0} / G_{1}$ phase of the cell cycle (possessing $2 \mathrm{C}$ DNA). This may require a knowledge of seed biology and/or additional experiments to find the most suitable tissue for a particular seed type/species. If dissection of the radicle is needed, sample preparation involves additional time and precision; for small seeds, the use of a microscope may be required. Seeds are usually produced in abundance, although they may be rare or absent in some populations and years, and thus not available for DNA content measurement. Also, they have to be used with caution because in some families hybridization between species may occur, the Rosaceae being an example [30].
Within the Rosaceae family, seeds of Cotoneaster have been used previously for flow cytometric DNA content measurement for ploidy estimation, using external standardization and a two-step procedure, involving centrifugation $[13,14]$. As shown here, this complex procedure can be successfully replaced by a simple and reliable one-step standard protocol, using the whole seed, the dissected radicle, or part of the seed containing the radicle. Such material is suitable for analysis without any other special pretreatment for sample preparation.

Our results demonstrate that the use of seeds may greatly simplify protocols in cases in which difficult leaf tissue requires special procedures. However, the simplification of protocols is one consideration among many. The final choice of tissue will depend on a variety of factors, including tissue availability, storage and transport concerns, the ease with which paternal DNA content can be inferred from that of progeny, requirements for sampling nonreproductive individuals, and the relative difficulty of seed and leaf preparation, both of which may vary considerably.

In conclusion, in the Rosaceae species containing staining inhibitors in the leaf cytosol, their seeds, which are free of such compounds, are a suitable alternative material for flow cytometric estimation of DNA content. The presence of staining inhibitors should be tested for each species, especially woody ones, regardless of the plant material used for measurement, and the composition of the nuclei-isolation buffer should be optimized for individual tissues/species. However, even after the addition of antioxidants, a stoichiometric error in the flow cytometric estimation of DNA content in "difficult" species can occur, and thus using plant parts that contain compounds which affect nuclei fluorescence should be avoided. 


\section{Abbreviations}

FCM: Flow cytometry

PI: $\quad$ Propidium iodide

PVP: Polyvinylpyrrolidone

SSC: Side scatter

FSC: Forward scatter

DF: Debris background factor.

\section{Acknowledgments}

The authors thank Professor J. D. Bewley and P. Kron (University of Guelph, Canada) for critical comments on the manuscript.

\section{References}

[1] E. E. Dickson, K. Arumuganathan, S. Kresovich, and J. J. Doyle, "Nuclear DNA content variation within the Rosaceae," American Journal of Botany, vol. 79, no. 9, pp. 1081-1086, 1992.

[2] N. Talent and T. A. Dickinson, "Polyploidy in Crataegus and Mespilus (Rosaceae, Maloideae): evolutionary inferences from flow cytometry of nuclear DNA amounts," Canadian Journal of Botany, vol. 83, no. 10, pp. 1268-1304, 2005.

[3] J. Doležel, J. Greilhuber, and J. Suda, "Estimation of nuclear DNA content in plants using flow cytometry," Nature Protocols, vol. 2, no. 9, pp. 2233-2244, 2007.

[4] J. Greilhuber, E. Temsch, and J. Loureiro, "Nuclear DNA content measurement," in Flow Cytometry with Plant Cells: Analysis of Genes, Chromosomes and Genomes, J. Doležel, J. Greilhuber, and J. Suda, Eds., pp. 67-101, Wiley-VCH, Weinheim, Germany, 2007.

[5] D. W. Galbraith, K. R. Harkins, J. M. Maddox, N. M. Ayres, D. P. Sharma, and E. Firoozabady, "Rapid flow cytometric analysis of the cell cycle in intact plant tissues," Science, vol. 220, no. 4601, pp. 1049-1051, 1983.

[6] J. Loureiro, E. Rodriguez, J. Doležel, and C. Santos, “Two new nuclear isolation buffers for plant DNA flow cytometry: a test with 37 species," Annals of Botany, vol. 100, no. 4, pp. 875-888, 2007.

[7] H. J. Price, G. Hodnett, and J. S. Johnston, "Sunflower (Helianthus annuus) leaves contain compounds that reduce nuclear propidium iodide fluorescence," Annals of Botany, vol. 86, no. 5, pp. 929-934, 2000.

[8] M. Noirot, P. Barre, J. Louarn, Ch. Duperray, and S. Hamon, "Nucleus-cytosol interactions-a source of stoichiometric error in flow cytometric estimation of nuclear DNA content in plants," Annals of Botany, vol. 86, no. 2, pp. 309-316, 2000.

[9] M. Noirot, P. Barre, C. Duperray, J. Louarn, and S. Hamon, "Effects of caffeine and chlorogenic acid on propidium iodide accessibility to DNA: consequences on genome size evaluation in coffee tree," Annals of Botany, vol. 92, no. 2, pp. 259-264, 2003.

[10] J. Loureiro, E. Rodriguez, J. Doležel, and C. Santos, "Flow cytometric and microscopic analysis of the effect of tannic acid on plant nuclei and estimation of DNA content," Annals of Botany, vol. 98, no. 3, pp. 515-527, 2006.

[11] K. Yokoya, A. V. Roberts, J. Mottley, R. Lewis, and P. E. Brandham, "Nuclear DNA amounts roses," Annals of Botany, vol. 85, no. 4, pp. 557-561, 2000.

[12] B. Thiem and E. Śliwińska, "Flow cytometric analysis of nuclear DNA content in cloudberry (Rubus chamaemorus L.) in vitro cultures," Plant Science, vol. 164, no. 1, pp. 129-134, 2003.

[13] N. Talent and T. A. Dickinson, "Endosperm formation in aposporous Crataegus (Rosaceae, Spiraeoideae, tribe Pyreae): parallels to Ranunculaceae and Poaceae," New Phytologist, vol. 173, no. 2, pp. 231-249, 2007.

[14] N. Talent and T. A. Dickinson, "The potential for ploidy level increases and decreases in Crataegus (Rosaceae, Spiraeoideae, tribe Pyreae)," Canadian Journal of Botany, vol. 85, no. 6, pp. 570-584, 2007.

[15] T. C. Tatum, S. Stepanovic, D. P. Biradar, A. L. Rayburn, and S. S. Korban, "Variation in nuclear DNA content in Malus species and cultivated apples," Genome, vol. 48, no. 5, pp. 924-930, 2005.

[16] A. Dzialuk, I. Chybicki, M. Welc, E. Śliwińska, and J. Burczyk, "Presence of triploids among oak species," Annals of Botany, vol. 99, no. 5, pp. 959-964, 2007.

[17] J. Greilhuber, "Cytochemistry and C-values: the less-wellknown world of nuclear DNA amounts," Annals of Botany, vol. 101, no. 6, pp. 791-804, 2008.

[18] E. Sliwinska, E. Zielinska, and I. Jedrzejczyk, "Are seeds suitable for flow cytometric estimation of plant genome size?" Cytometry Part A, vol. 64, no. 2, pp. 72-79, 2005.

[19] K. Anamthawat-Jónsson, Æ. Th. Thórsson, E. M. Temsch, and J. Greilhuber, "Icelandic birch polyploids-the case of perfect fit in genome size," accepted in Journal of Botany.

[20] E. Sliwinska, I. Pisarczyk, A. Pawlik, and D. W. Galbraith, "Measuring genome size of desert plants using dry seeds," Botany, vol. 87, no. 2, pp. 127-135, 2009.

[21] E. Sliwinska, "Nuclear DNA content analysis of plant seeds by flow cytometry," in Current Protocols in Cytometry, J. P. Robinson, Z. Darzynkiewicz, P. N. Dean, et al., Eds., pp. 7.29.1-7.29.13, John Wiley \& Sons, New York, NY, USA, 2006.

[22] E. Sliwinska, "Nuclear DNA replication and seed quality," Seed Science Research, vol. 19, no. 1, pp. 15-25, 2009.

[23] J. Loureiro, E. Rodriguez, Â. Gomes, and C. Santos, "Genome size estimations on Ulmus minor Mill., Ulmus glabra Huds., and Celtis australis L. using flow cytometry," Plant Biology, vol. 9, no. 4, pp. 541-544, 2007.

[24] D. Marie and S. C. Brown, "A cytometric exercise in plant DNA histograms, with $2 \mathrm{C}$ values for 70 species," Biology of the Cell, vol. 78, no. 1-2, pp. 41-51, 1993.

[25] M. A. Lysák and J. Doležel, "Estimation of nuclear DNA content in Sesleria (Poaceae)," Caryologia, vol. 51, no. 2, pp. 123-132, 1998.

[26] A. V. Roberts, Th. Gladis, and H. Brumme, "DNA amounts of roses (Rosa L.) and their use in attributing ploidy levels," Plant Cell Reports, vol. 28, no. 1, pp. 61-71, 2009.

[27] E. Sliwinska and B. Thiem, "Genome size stability in six medicinal plant species propagated in vitro," Biologia Plantarum, vol. 51, no. 3, pp. 556-558, 2007.

[28] H. J. Price and J. S. Johnston, "Influence of light on DNA content of Helianthus annuus Linnaeus," Proceedings of the National Academy of Sciences of the United States of America, vol. 93, no. 20, pp. 11264-11267, 1996.

[29] H. J. Price, P. W. Morgan, and J. S. Johnston, "Environmentally correlated variation in 2C nuclear DNA content measurements in Helianthus annuus L.", Annals of Botany, vol. 82, pp. 95-98, 1998.

[30] P. Kron and B. C. Husband, "Hybridization and the reproductive pathways mediating gene flow between native Malus coronaria and domestic apple, M. domestica," Botany, vol. 87, no. 9, pp. 864-874, 2009. 
[31] G. Pinto, J. Loureiro, T. Lopes, and C. Santos, "Analysis of the genetic stability of Eucalyptus globulus Labill. somatic embryos by flow cytometry," Theoretical and Applied Genetics, vol. 109, no. 3, pp. 580-587, 2004.

[32] F. Baluška, "Nuclear size, DNA content, and chromatin condensation are different in individual tissues of the maize root apex," Protoplasma, vol. 158, no. 1-2, pp. 45-52, 1990.

[33] D. P. Biradar and A. L. Rayburn, "Flow cytometric probing of chromatin condensation in maize diploid nuclei," New Phytologist, vol. 126, no. 1, pp. 31-35, 1994.

[34] M. D. Bennett and I. J. Leitch, "Plant DNA C-values Database," release 4.0, October 2005, http://data.kew.org/cvalues.

[35] S. S. Korban, W. Wannarat, C. M. Rayburn, T. C. Tatum, and A. L. Rayburn, "Genome size and nucleotypic variation in Malus germplasm," Genome, vol. 52, no. 2, pp. 148-155, 2009. 

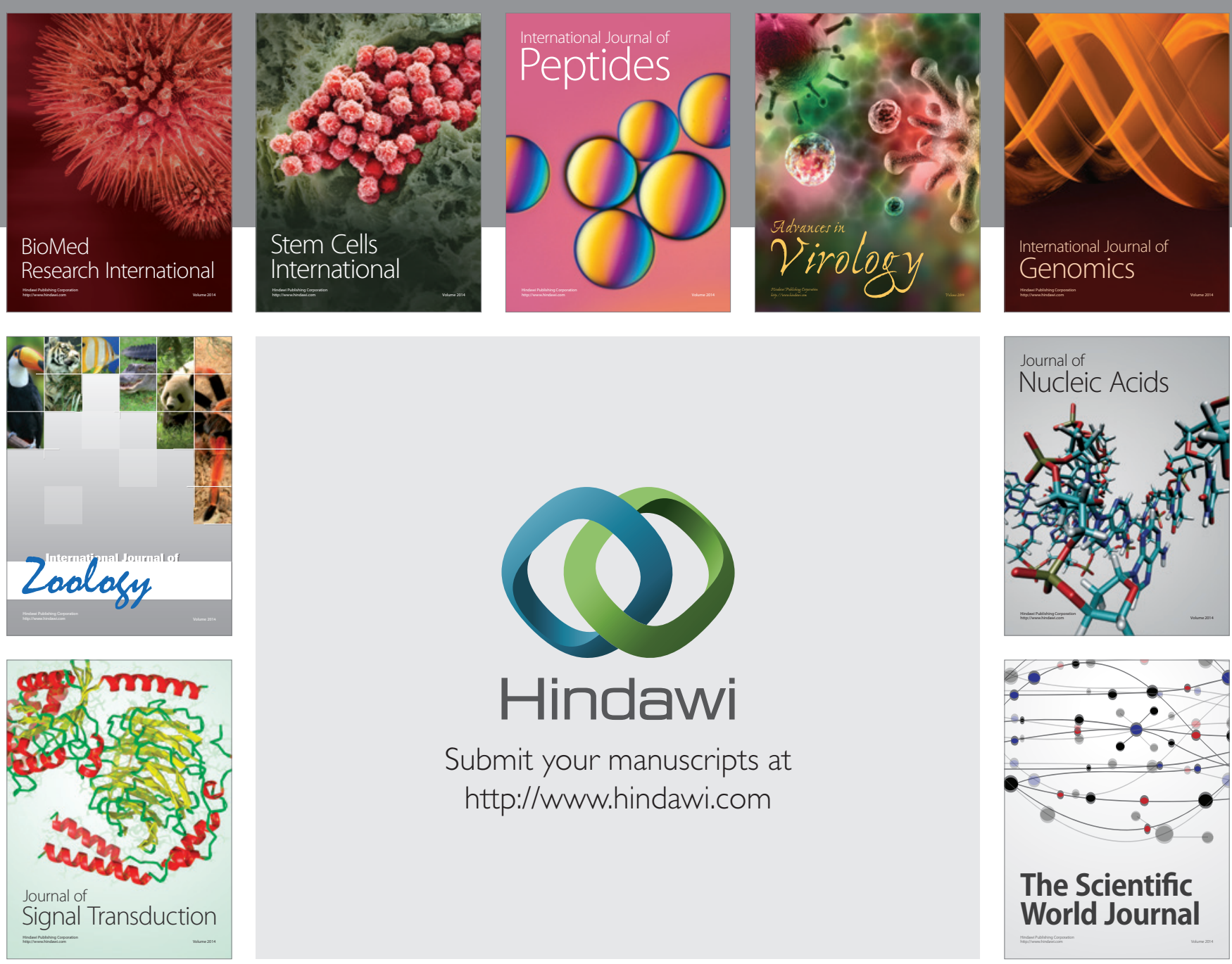

Submit your manuscripts at

http://www.hindawi.com
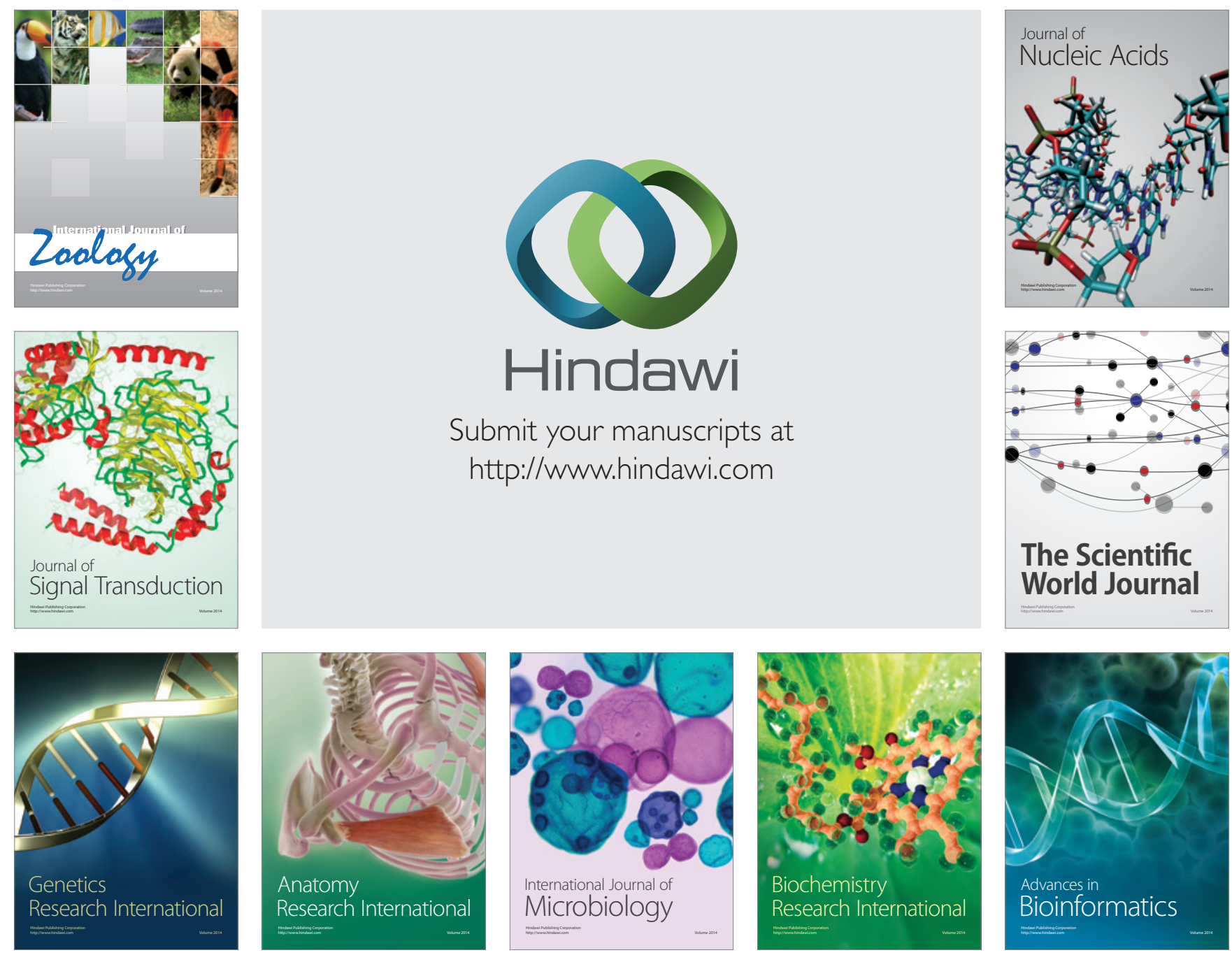

The Scientific World Journal
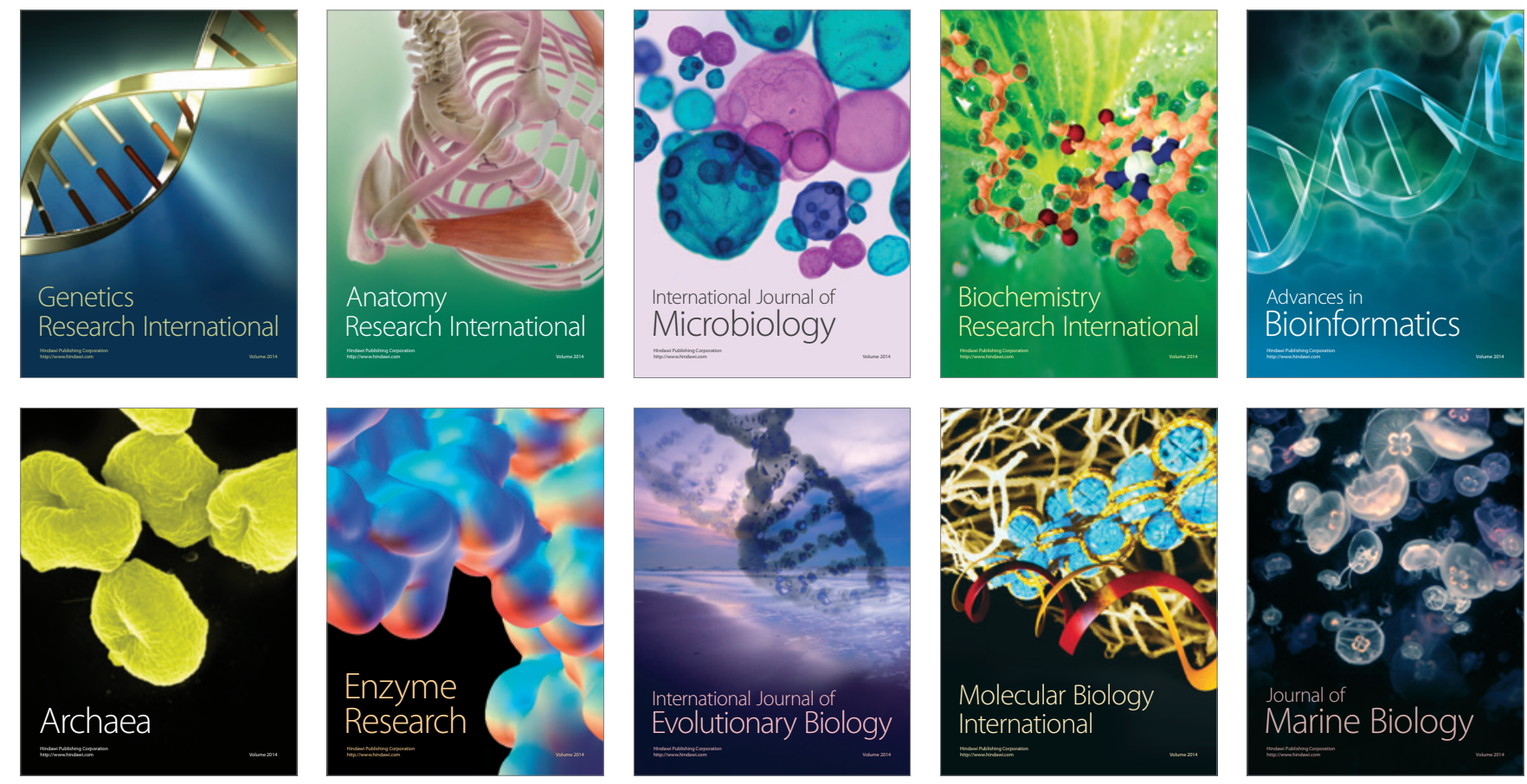